Research Article

\title{
The Outcomes of Primary Debulking Surgery and Neoadjuvant Chemotherapy in Advanced Ovarian Cancer
}

\section{Luaran Bedah Primer Debulking dengan Kemoterapi Neoajuvan pada Kanker Ovarium Stadium Lanjut}

\author{
Dino Rinaldy', Andrijono', Bambang Sutrisna ${ }^{2}$ \\ ${ }^{1}$ Division of Oncology, Department of Obstetrics and Gynecology, \\ Faculty of Medicine University of Indonesia \\ ${ }^{2}$ Community Medicine, Department of Public Health, University of Indonesia
}

Jakarta

\begin{abstract}
Objective: To compare the outcomes and survival rate of primary debulking surgery with neoadjuvant chemotherapy.

Method: We selected advanced ovarian cancer patients from medical records. Subjects were allocated into groups of primary debulking surgery and neoajuvant chemotherapy by considering the inclusion and exclusion criteria. We analyzed the data using $\mathrm{T}$ test, Fisher's exact, and chi-square. The survival rate was presented in Kaplan Meier curve, whereas the significance was tested with Logrank. We managed the data using STRATA software version 12.

Result: We obtained 32 cases of primary debulking surgery group and 20 cases of the neoadjuvant chemotherapy group. Most of the subjects (44.2\%) were $40-49$ years old and $80.8 \%$ had delivered more than twice. The mean value of Ca-125 at admission was $3,594.8 \mathrm{u} / \mathrm{ml}$ (range 66.6 to $73,000 \mathrm{u} / \mathrm{ml}$ ). Total of 31 subjects showed the serous histologic type (59.6\%). There was no association between primary debulking surgery and neoadjuvant chemotherapy for the parameter of operative time, blood loss, organs injury, ICU stay, and hospital stay ( $p>0.05$ ). Primary debulking surgery had a survival rate similar to neoadjuvant chemotherapy group $(\mathrm{p}=0.95)$.

Conclusion: The perioperative outcomes of advanced ovarian cancer patients has similar result between primary debulking surgery and neoadjuvant chemotherapy. Primary debulking surgery has a survival rate similar to neoadjuvant chemotherapy group.

[Indones J Obstet Gynecol 2016; 4-2: 111-115]
\end{abstract}

Keywords: advanced ovarian cancer, neoadjuvant chemotherapy, primary debulking surgery

\begin{abstract}
Abstrak
Tujuan: Membandingkan luaran dan angka kebertahanan hidup antara bedah debulking primer dengan kemoterapi neoajuvan.

Metode: Peneliti mengambil pasien kanker ovarium stadium lanjut dari rekam medik. Subjek dialokasikan ke dalam kelompok bedah debulking primer dan kemoterapi neoajuvan dengan mempertimbangkan kriteria inklusi dan eksklusi. Data dianalisis dengan uji T, Fisher exact, dan chi-square. Angka kebertahanan hidup ditampilkan dalam kurva Kaplan Meier di mana kemaknaan diuji dengan Logrank. Kami mengolah data menggunakan software Strata versi 12.
\end{abstract}

Hasil: Kami mendapat 32 kasus bedah debulking primer dan 20 kasus dari kelompok kemoterapi neoajuvan. Kebanyakan subjek (44,2\%) berusia 40-49 tahun dan 80,8\% pernah melahirkan lebih dari 2 kali. Rerata nilai Ca-125 saat masuk ialah 3.594,8 U/ml (66,6 hingga $73.000 \mathrm{U} / \mathrm{ml}$. Sebanyak 31 subjek memperihatkan tipe histologi serosa $(59,6 \%)$. Tidak ada hubungan antara bedah debulking primer dengan kemoterapi neoajuvan untuk luaran waktu operasi, jumlah hilang darah, kerusakan organ, lama tinggal di ruang rawat intensif maupun RS $(p>0,05)$. Bedah debulking primer memiliki angka kebertahanan hidup mirip dengan kelompok kemoterapi neoajuvan $(p=0,95)$.

Kesimpulan: Luaran pasien kanker ovarium stadium lanjut yang dilakukan bedah debulking primer mirip dengan yang dilakukan kemoterapi neoajuvan. Bedah debulking primer memiliki angka kebertahanan hidup mirip dengan kelompok kemoterapi neoajuvan.

[Maj Obstet Ginekol Indones 2016; 4-2: 111-115]

Kata kunci: bedah debulking primer, kanker ovarium stadium lanjut, kemoterapi neoajuvan

Correspondence. Dino Rinaldy. Telephone:0812-7209629; Email: dokterdino@gmail.com

\section{INTRODUCTION}

In $2009,21,550$ women were diagnosed with ovarian cancer and 14,600 of them died due to the disease. The ovarian cancer was the fifth most common causes of death from malignancy. In the United States, an estimated 1 of 72 women would develop the ovarian cancer in their lifetime and 1 of 100 women would die because of the disease. ${ }^{1}$ In Europe, there were 61,000 new cases diagnosed and 39,000 deaths from ovarian cancer occurred annually. ${ }^{2}$
In Indonesia, cancer was the fifth causes of death. It was because the life expectancy rate is increased so that automatically, it will rise the degenerative disease; one of which is cancer. Life expectancy rate is related to the improvement of socioeconomic condition. More than $40 \%$ of women malignancies are gynecological cancers. ${ }^{3}$

Advanced epithelial ovarian cancer typically presents with widely disseminated intraabdominal disease. The standard treatment of advanced epithelial ovarian cancer includes primary cytoreduc- 
tion or debulking surgery followed by adjuvant systemic chemotherapy. ${ }^{1}$ Surgical cytoreduction of advanced stage ovarian cancer, also termed "tumor debulking", is defined as an attempt to maximally resect all visible and palpable disease. ${ }^{4}$

The ideally curative surgical approach to the cancer is through en-bloc resection of the tumor with wide margin of normal tissue. Unluckily, this method is not appropriate to most of ovarian cancer patients due to the existence of diffuse metastases to vital structures at the time of diagnosis. Therefore, the aim for these patients is to reduce the tumor burden as much as possible. ${ }^{5}$

The most effective surgical cytoreduction intends to reach the minimal risk of residual status. The microscopic residual disease has correlation with the overall survival rate in patients with advanced disease. ${ }^{1,6}$

In selected cases which it predicts that complete or optimal surgical cytoreduction will not be achieved at primary surgery, we should perform the neoadjuvant chemotherapy followed by inter- val debulking surgery (delayed primary surgery). Recent study showed that neoadjuvant chemotherapy followed by interval debulking surgery in the bulky stage III and stage IV disease was not inferior to primary surgery. ${ }^{7}$

Some gynecologist has suggested this approach, especially for the treatment of stage IV ovarian cancer or for patients with very high metastatic tumor load (for example the mass was more than 1,000 grams) or in patients with poor general condition. ${ }^{8}$ Several advantages of neoadjuvant chemotherapy are such as a reduced risk of perioperative morbidity, a higher rate of optimal resection, and the contention that survival is not compromised by deferring the initial attempt at surgical debulking. ${ }^{9}$

Interval debulking surgery in patients with advanced stage of ovarian cancer offered the same chance of survival as primary debulking surgery; however, interval debulking surgery showed better toleration. ${ }^{10}$ Therefore, this study aims to compare the outcomes of primary debulking surgery with neoadjuvant chemotherapy.

Table 1. The Characteristics of Patients.

\begin{tabular}{|c|c|c|c|}
\hline Variable & $\begin{array}{l}\text { Primary Debulking } \\
\text { Surgery }(\mathrm{N}=32)\end{array}$ & $\begin{array}{l}\text { Neoadjuvant Chemo- } \\
\text { therapy }(\mathrm{N}=20)\end{array}$ & $p$ value \\
\hline Mean of age - years old & 49.1 & 48.7 & $0.55^{*}$ \\
\hline \multicolumn{4}{|l|}{ Parity - N (\%) } \\
\hline Nulliparity & $1(3.1)$ & $2(10.0)$ & $0.55^{* *}$ \\
\hline Primiparity & $4(12.5)$ & $3(15.0)$ & \\
\hline Multiparity & $27(84.4)$ & $15(75.0)$ & \\
\hline \multicolumn{4}{|l|}{ FIGO stage - N (\%) } \\
\hline IIIC & $29(90.6)$ & $15(75.0)$ & $0.24^{* * *}$ \\
\hline IV & $3(9.4)$ & $5(25.0)$ & \\
\hline Mean of serum Ca-125 at entry $(\mathrm{U} / \mathrm{ml})$ & 1661.9 & 6687.36 & $0.05^{*}$ \\
\hline \multicolumn{4}{|l|}{ Histologic type - N (\%) } \\
\hline Serous & $16(50)$ & $15(75.0)$ & $0.19^{* *}$ \\
\hline Endometrioid & $9(28.1)$ & $3(15.0)$ & \\
\hline Mucinous & $3(9.4)$ & $2(10.0)$ & \\
\hline Clear cell & $4(12.5)$ & 0 & \\
\hline \multicolumn{4}{|l|}{ Histologic grade - N (\%) } \\
\hline Well differentiated & $3(9.4)$ & $5(25.0)$ & \\
\hline Moderately differentiated & $15(46.9)$ & $8(40.0)$ & \\
\hline Poorly differentiated & $14(43.8)$ & $7(35.0)$ & \\
\hline \multicolumn{4}{|l|}{ Degree of cytoreduction - N (\%) } \\
\hline Complete macroscopic resection & $9(28.1)$ & $9(45.0)$ & $0.44^{* *}$ \\
\hline Optimal cytoreduction & $5(15.6)$ & $3(15.0)$ & \\
\hline Suboptimal cytoreduction & $18(56.3)$ & $8(40.0)$ & \\
\hline
\end{tabular}

*t-test, ${ }^{* *}$ chi-square, ${ }^{* * *}$ fisher exact 


\section{METHODS}

We obtained the data from stage IIIC and IV epithelial ovarian cancer patients' medical record. Each patient was classified into the group of primary debulking surgery and neoadjuvant chemotherapy. We needed 30 samples of each group. The perioperative outcomes were consisted of duration of surgery, intraoperative blood loss, intraoperative organs injury, length of stay in intensive care unit (ICU), and also the total hospitalization time.

We analyzed the data using $\mathrm{T}$ test for the numerical data and Fisher's exact also chi-square for the categorical data. The survival rate for both groups were calculated from the date of surgery to death (event). Survival rate was presented in Kaplan Meier curve, whereas the significance was tested with Logrank. We managed the data using STRATA software version 12.

\section{RESULTS}

We could not fulfill the required samples due to the difficulty of searching the medical records. In our study, we obtained 32 cases of primary debulking surgery group and 20 cases of the neoadjuvant chemotherapy group. Most of the subjects (44.2\%) were $40-49$ years old and $80.8 \%$ had delivered more than twice. The mean value of Ca-125 at admission was $3,594.8 \mathrm{u} / \mathrm{ml}$ (range 66.6 to 73,000 $\mathrm{u} / \mathrm{ml}$ ). Total of 31 subjects showed the serous histologic type $(59.6 \%)$. The characteristics of patients were distributed in Table 1.

In our study, there was no association between primary debulking surgery and neoadjuvant chemotherapy for the parameter of operative time, blood loss, organs injury, ICU stay, and hospital stay (Table 2). Figure 1 described the overall survival rates based on treatment options.

Table 2. Perioperative Morbidity in Both Study Groups.

\begin{tabular}{lccc}
\hline \hline Variable & $\begin{array}{c}\text { Primary Debulking } \\
\text { Surgery (N=32) }\end{array}$ & $\begin{array}{c}\text { Neoadjuvant Chemo- } \\
\text { therapy (N=20) }\end{array}$ & $\begin{array}{c}\text { p value } \\
\text { (t test) }\end{array}$ \\
\hline Operative time (min) & 244.8 & & 0.70 \\
$\quad$ Mean & $105-510$ & 229.5 & \\
Range & & $165-375$ & 0.66 \\
Blood loss rate (ml) & $1,704.7$ & $1,152.5$ & \\
$\quad$ Mean & $300-13,000$ & $400-2,100$ & 0.57 \\
$\quad$ Range & 3 & 1 & 0.57 \\
Organs injury ICU stay (days) & 0.3 & 0.3 & \\
$\quad$ Mean & $0-2$ & $0-2$ & 0.78 \\
$\quad$ Range & & & \\
Hospital stay (days) & 8.3 & 7.5 & \\
Mean & $5-17$ & $5-14$ & \\
Range & & & \\
\hline \hline
\end{tabular}

*chi-square

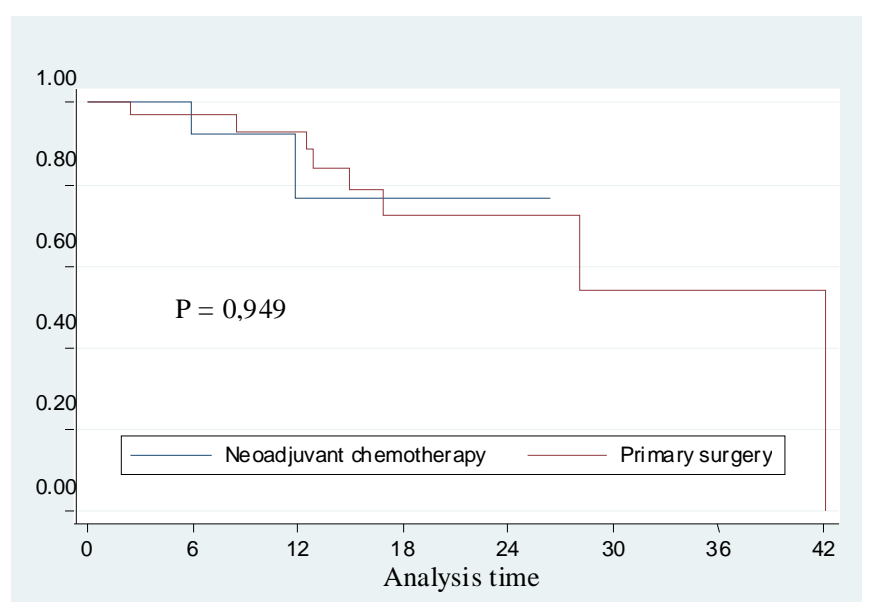

Figure 1. Overall Survival Rate According to the Treatment Options. 


\section{DISCUSSION}

\section{Length of Surgery}

Hou, et al. showed that the average length of surgery was significantly lower in the neoadjuvant chemotherapy compared with primary debulking surgery group (211 min vs. $276 \mathrm{~min}, \mathrm{p}<0.001){ }^{11}$ However, a study by Hegazy, et al. indicated the conflicting result where the average duration of the operation on neoadjuvant group was 150 minutes, while for primary surgery group was over 190 minutes. There was no significant difference between two groups in statistic. ${ }^{12}$ Their result was similar to Kuhn, et al. study. Kuhn said that the average length of surgery for primary debulking surgery and neoadjuvant chemotherapy were 270 and 260 minutes. They found no significant relationship on length of surgery between two groups. ${ }^{13}$ Our study had similar results with study by Hegazy et al. and Kuhn et al. The average length of surgery was 245 minutes versus 230 minutes, also we found no significant difference in duration of surgery between two groups $(p=0.70)$.

\section{Blood Loss Rates}

Hou, et al. studied 172 patients of advanced stage epithelial ovarian cancer consisting of 109 patients performing the primary debulking surgery and 63 patients undergoing the neoadjuvant chemotherapy from 1998 to 2005. Patients receiving neoadjuvant chemotherapy experienced significantly less blood loss during surgery $(\mathrm{p}<0.001) .{ }^{11}$ The same result was also reported by Hegazy, et al. They reported that the group with neoadjuvant chemotherapy had significantly less blood loss during surgery $(\mathrm{p}=0.02) .{ }^{12}$ Our study found the average blood loss in the neoadjuvant chemotherapy group was $1,152.5 \mathrm{ml}$, while the primary debulking surgery group was $1,704.7 \mathrm{ml}$. Clinically, the amount of bleeding was higher in the primary debulking surgery group; yet the statistical test had shown no difference between the two groups $(p=0.34)$.

\section{Organs Injury}

Kuhn, et al. in a retrospective study involving stage IIIC ovarian cancer patients including 31 patients received neoadjuvant chemotherapy and 32 patients were allocated to the primary debulking surgery group. The result showed that 11 and 9 women were found injured at the primary debulk- ing surgery and neoadjuvant chemotherapy group. They did not find the difference in intraoperative organs injury. ${ }^{13}$ Similar result was reported by Hegazy, et al. where they did not find a significant association between therapy modality and intraoperative organs injury. ${ }^{12}$ Our study released the similar result to both study above.

\section{Hospital and ICU Stay}

Hegazy, et al in their study showed that neoadjuvant chemotherapy group was shorter in length of hospital $(\mathrm{p}=0.05)$ and ICU stay $(\mathrm{p}=0.03)$ significantly. ${ }^{12}$ Contrary to the result stated by Hegazy, et al., Hou, et al., in their study involving 172 patients, they concluded that there was no significant association between administration of neoadjuvant chemotherapy and length of stay in hospital also ICU. ${ }^{11}$ Of all the perioperative outcome variables, neoadjuvant chemotherapy group experienced shorter operative time, less blood loss, and shorter treatment duration. Neoadjuvant chemotherapy group offered better clinical outcome compared with primary debulking surgery despite lack of statistical evidence.

\section{Overall Survival Rate}

Vergote, et al. in a multicenter study involving 718 patients, reported that the median overall survival rate of primary debulking surgery group was 29 months, whereas in the neoadjuvant chemotherapy group was 30 months. There was no statistical difference in survival rate between the two groups $(p=0.98) .{ }^{14}$ Hegazy, et al. also declared similar result to study stated above. Primary debulking surgery group had median overall survival rate of 28 months, whereas in the chemotherapy group was 25 months; however, it was not statistically different ( $\mathrm{p}=0.5) .{ }^{12}$ Loizzi, et al. in a case-control study examined the outcomes of primary debulking surgery and neoadjuvant chemotherapy in advanced ovarian cancer. The result did not differ statistically. $(p=0.66) .{ }^{15}$ Steed, et al. also reported that there was no significant difference in terms of progression-free survival (PFS) $(\mathrm{HR}=1.61 ; \mathrm{p}=0.04$; 95\% CI=1.03-2.53) and overall survival (OS) (HR=1.85; $\mathrm{p}=0.03,95 \% \mathrm{CI}=1.06-3.23$ ) rate for both groups. It was the only one study that stating both groups had the same survival rate. ${ }^{16}$ Our study also confirmed that both groups had the same overall survival rate. 


\section{CONCLUSION}

The perioperative outcomes of advanced ovarian cancer patients has similar result between primary debulking surgery and neoadjuvant chemotherapy. However, through clinical judgement, neoadjuvant chemotherapy group has better perioperative outcomes compared with primary surgery group. Primary debulking surgery has a survival rate similar with neoadjuvant chemotherapy group.

\section{CONFLICT OF INTEREST}

The author(s) declared no potential conflicts of interest with respect to the research, authorship, and/or publication of this article. We received no financial support for the research, authorship, and/or publication of this article.

\section{REFERENCES}

1. Bristow RE, Amstrong DK, editors. Ovarian Cancer. $1^{\text {st }}$ ed. Philadelphia: Saunders; 2010.

2. Colombo N, Gorp TV, Parma G, Amant F, Gatta G, Sessa C, et al. Ovarian Cancer. Critical Reviews in Oncology/Hematology. 2006; 60: 159-79.

3. Aziz MF. Gynecological cancer in Indonesia. J Gynecol Oncol. 2009; 20(1): 8-10.

4. Zizanovic 0, Aldini A, Carlson JW, Chi DS. Advanced cytoreductive surgery: American perspective. Gynecol Oncol. 2009; 114: 3-9.

5. Bristow RE, Karlan BY, editors. Surgery for ovarian cancer principles and practice. United Kingdom: Taylor \& Francis. 2007.

6. Ibeanu OA, Bristow RE. Predicting the outcome of cytoreductive surgery for advanced ovarian cancer a review. Int J Gynecol Cancer. 2010; 20: 1-11.
7. Elattar A, Bryant A, Winter-Roach BA, Hatem M, Naik R. Optimal primary surgical treatment for advanced epithelial ovarian cancer (Review). The Cochrane Collaboration. 2011; 8.

8. Vergote I, Amant F, Kristensen G, et al. Primary surgery or neoadjuvant chemotherapy followed by interval debulking surgery in advanced ovarian cancer. Eur J Cancer. 2011; 47: 88-92.

9. Bristow RE, Eisenhauer EL, Santillan A, et al. Delaying the primary surgical effort for advanced ovarian cancer: A systematic review of neoadjuvant chemotherapy and interval cytoreduction. Gynecol Oncol. 2007; 104: 480-90.

10. Morice P, Brehier-Ollive D, Rey A, et al. Results of interval debulking surgery in advanced stage ovarian cancer: an exposed-non-exposed study. 2003; 14: 74-7.

11. Hou JY, Kelly MG, Yu H, et al. Neoadjuvant chemotherapy lessens surgical morbidity in advanced ovarian cancer and leads to improved survival in stage IV disease. 2007; 105: 211-7.

12. Hegazy MA, Hegazi RA, Elshafei MA, et al. Neoadjuvant chemotherapy versus primary surgery in advanced ovarian carcinoma. World J Sur Oncol. 2005; 3: 57.

13. Kuhn W, Rutke S, Späthe K, et al. Neoadjuvant chemotherapy followed by tumor debulking prolongs survival for patients with poor prognosis in International Federation of Gynecology and Obstetrics Stage IIIC ovarian carcinoma. Cancer. 2001; 92: 2585-91.

14. Vergote I, Tropé CG, Amant F, et al. Neoadjuvant Chemotherapy or Primary Surgery in Stage IIIC or IV Ovarian Cancer. N Engl J Med. 2010; 363: 943-53.

15. Loizzi V, Cormio G, L. Restay Car, et al,. Neoadjuvant chemotherapy in advanced ovarian cancer: a case-control study. Int J Gynecol Cancer. 2005; 15.

16. Steed H OA, Murphy J, Laframboise S, et al, A retrospective analysis of neoadjuvant platinum-based chemotherapy versus up-front surgery in advanced ovarian cancer. Int J Gynecol Cancer. 2006; suppl 1: 47-53. 